\title{
Perlindungan Terhadap Konsumen Dalam Jual Beli Rumah Melalui Developer di Kota Denpasar
}

\author{
Oleh \\ Ni Putu Yunika Sulistyawati, SH.,M.Kn \\ Ni Made Yuniari, S.Pd.,M.Pd \\ I Nyoman Agus Trisnadiasa.,SH.,M.H
}

\begin{abstract}
The results of research entitle the protection of consumers in buying and selling houses through developers in Denpasar is only limited on minor damages when the guarantee given by the developer, in the case of buying and selling houses through developers in Denpasar concerning the issue of consumer rights both safety, comfort and security in occupy housesthat are purchased through the Developer. As for the resolution of the problem between the developer and the consumer in Article 52 of Law Number 8 of 1999 concerning Consumer Protection and the absence of a settlement in the court institution. In the empirical level, the solution is choosing a consensus and if there is no agreement between the two parties, then asking help from the Notary as the mediator is needed. The constraints faced by developers and consumers in resolving disputes of law No. 8 of 1999 concerning consumer protection, namely the constraints faced by socio-juridical namely due to the lack of understanding of consumers and developers toward the existence of the Consumer Protection Act, andthe lack of socialization in the community about the existence of the Consumer Protection Act. In this case, the non-juridical constraints due to the lack of human resources, both those that are on the developer and the consumers, beside that the facilities and devices do not support it. Therefore, the efforts would be made in order to be able to resolve the problem of housing consumer dispute in Denpasar. Another obstacle is the lack of consumers' aspirations in choosingthe resolution of the consumer dispute until the judicial route. The efforts that is made both by developers and consumers in dealing with obstacles in the settlement of buying and selling houses through developers, namely: legal protection for the people. It is divided into 2, Preventive Efforts (Preventive) and Refressive efforts.
\end{abstract}

Keywords: Consumer; Buy and sell; Develover

\section{PENDAHULUAN}

Rumah merupakan kebutuhan pokok manusia yang sangat penting. Untuk itu konsumen dalam prakteknya menggunakan berbagai macam cara untuk mendapatkan rumah. Misalnya seperti, membeli rumah melalui developer maupun pihakpihak bank yang memberikan jaminan kredit kepemilikan rumah.

Pihak swasta yang lazimnya disebut "Developer", dalam pelaksanaan partisipasinya pada pembangunan perumahan, biasanya karena kebutuhan dan mencari kepraktisan dalam bidang usaha pada tahap pra transaksi menyebarkan iklan atau brosur perumahan yang akan dijual. Pada tahap transaksi, syarat-syarat dalam pembayaran yang ada dalam brosur umumnya direalisasikan sebagai materi perjanjian jual beli, pernyataanpernyataan kesanggupan membayar atau tanda bukti pembayaran dalam bentuk kwitansi. Isi brosur perumahan ini distandarkan secara sepihak oleh developer dan hanya memuat materi kewajiban konsumen tanpa mengatur hak konsumen, baik yang menyangkut hak atas 
Perlindungan Terhadap Konsumen dalam Jual Beli Rumah. ..(Ni Putu Yunika Sulistyawati, Ni Made Yuniari, I Nyoman Agus Trisnadiasa, 18-26 )

keselamatan, kenyamanan, dan keamanan dalam menempati rumah yang dibeli melalui pihak developer. Dalam hal ini pemilik rumah atau konsumen merasa aman, dijamin kepastian hukum sebagai seorang konsumen. Sejauh ini bahkan tidak ada kewajiban atau tanggung jawab pengusaha yang bersangkutan. Bagi konsumen karena kurangnya pendidikan atau kemampuan dan kemandirian melindungi diri serta ingin cepat mendapatkan rumah, terpojok dalam posisi,selain itu diharapkan nantinya konsumen perumahan memperoleh hak dan kewajiban yang dilindungi yang dituangkan dalam perjanjian

Dalam permasalahan jual beli rumah dengan developer, pihak developer hanya memberikan jaminan selama satu sampai dua bulan pada konsumen. Itupun hanya sebatas kerusakan kecil. Apabila rumah yang dibeli mengalami kerusakan setelah masa jaminan itu selesai maka pihak developer tidak akan menjamin apapun jenis kerusakan rumah tersebut. Dalam hal ini menjadi tanggung jawab konsumen itu sendiri. Kondisi tersebut seringkali menimbulkan perselisihan atau sengketa antara konsumen dengan pihak developer.

Berdasarkan pada uraian ini, sangat menarik untuk diteliti tentang masalah: (1) Bagiamakah Perlindungan terhadap Konsumen Dalam Jual Beli Rumah Melalui Developer di Kota Denpasar ; (2) Kendala-kendala yang dihadapi oleh developer maupun konsumen dalam menyelesaikan sengketa Undang-Undang Nomor 8 tahun 1999, tentang Perlindungan Konsumen (3) Upaya-upaya apakah yang dilakukan baik oleh developer maupun konsumen dalam mengatasi hambatan tersebut;

\section{II.PEMBAHASAN}

\section{Perlindungan terhadap konsumen dalam jual beli rumah melalui developer dikota denpasar}

Para konsumen merupakan golongan yang rentan dieksploitasi oleh pelaku usaha dan diperlukan seperangkat aturan hukum untuk melindungi konsumen. Konsumen adalah "pengguna akhir" (end user) dari suatu produk, yaitu setiap pemakai barang dan atau jasa yang tersedia dalam masyarakat, baik bagi kepentingan diri sendiri, keluarga, orang lain, maupun makhluk hidup lain dan tidak untuk diperdagangkan.

Produsen atau pelaku usaha adalah setiap perorangan atau badan usaha yang didirikan dan berkedudukan atau melakukan kegiatan dalam wilayah hukum negara Republik Indonesia, baik sendiri-sendiri maupun bersama-sama melalui perjanjian menyelenggarakan kegiatan usaha dalam berbagai kegiatan ekonomi. Tentang perlindungan konsumen ini diatur oleh seperangkat aturan hukum di bidang perlindungan konsumen.

Menurut Pasal 1 Undang-Undang Perlindungan Konsumen bahwa yang dimaksud dengan Perlindungan Konsumen adalah : "Segala upaya yang menjamin adanya kepastian hukum untuk memberi perlindungan konsumen".

Menurut Pasal 1 ayat (2) Undang-Undang Perlindungan Konsumen adalah setiap orang pemakai barang dan/atau jasa yang tersedia dalam masyarakat, baik bagi kepentingan diri sendiri, keluarga, orang lain maupun makhluk hidup lain dan tidak untuk diperdagangkan.

Menurut Munir Fuady definisi konsumen adalah :

"Pengguna akhir" (end user) dari satu produk, yaitu setiap pemakai barang dan jasa yang tersedia dalam masyarakat, baik bagi kepentingan diri sendiri, keluarga, orang lain, maupun mahluk hidup lain dan untuk diperdagangkan".

Menurut Pasal 2 Undang-Undang Perlindungan Konsumen. Perlindungan konsumen berasaskan manfaat, keadilan, keseimbangan, keamanan dan keselamatan konsumen serta kepastian hukum.

Produsen sebagai pelaku usaha mempunya tugas dan kewajiban untuk ikut serta menciptakan dan menjaga iklim usaha yang sehat yang menunjang bagi pembangunan perekonomian nasional secara keseluruhan. Karena itu, kepada produsen dibebankan tanggung jawab atas pelaksanaan tugas dan kewajiban itu, yaitu melalui penerapan norma-norma hukum, kepatutan, dan menjunjung tinggi kebiasaan yang berlaku di kalangan dunia usaha. Etika bisnis merupakan salah 
satu pedoman bagi setiap pelaku usaha. Prinsip business is business, tidak dapat diterapkan, tetapi harus dengan pemahaman atas prinsip bisnis untuk pembangunan. Jadi, sejauh mungkin, pelaku usaha harus bekerja keras untuk menjadikan usahanya memberi kontribusi pada peningkatan pembangunan nasional secara keseluruhan.

Prinsip tentang tanggung jawab merupakan perihal yang sangat penting dalam hukum perlindungan konsumen. Dalam kasuskasus pelanggaran hak konsumen, diperlukan kehati-hatian dalam menganalisis pihak yang harus bertanggung jawab dan seberapa jauh tanggung jawab dapat dibebankan kepada pihak-pihak terkait.

Seseorang yang dirugikan karena memakai atau mengkonsumsi produk yang cacat hanya akan mendapat penggantian kerugian apabila mengajukan permintaan atau tuntutan atas hal tersebut. Permintaan atau penuntutan penggantian kerugian ini mutlak dilakukan oleh orang yang merasa berhak untuk mendapatkannya. Tidak akan ada penggantian kerugian selain karena dimohonkan terlebih dahulu ke pengadilan dengan syarat-syarat tertentu.

Menurut Pasal 19 ayat (1) dan ayat (3) UndangUndang Perlindungan Konsumen ini, konsumen yang merasa dirugikan dapat menuntut secara langsung penggantian kerugian kepada produsen, dan produsen harus memberi tanggapan dan/atau penyelesaian dalam jangka waktu tujuh hari setelah transaksi berlangsung. Misalnya, seseorang membeli barang yang terbungkus secara rapi. Setelah sampai di rumah, barang dibuka dan ternyata cacat/rusak. Konsumen pembeli dapat dengan langsung menuntut penjual untuk mengganti barang tersebut atau mengembalikan uang pembeliaannya. Hal ini harus diselesaikan dalam jangka waktu tujuh hari setelah terjadinya jual beli tersebut, yang berarti juga, pembeli harus dengan segera mengajukan tuntutannya.

Cara yang dimaksud oleh Pasal 19 ayat (1) itu tidak jelas. Akan tetapi dengan menyimak Pasal 19 ayat (3), pastilah yang dimaksud bukan melalui suatu badan dengan acara pemeriksaan tertentu. Penetapan jangka waktu tujuh hari setelah tanggal transaksi sebagaimana disebut dalam Pasal 19 ayat (3), maka dapat diduga bahwa penyelesaian sengketa yang dimaksudkan di sini bukanlah penyelesaian yang rumit dan melalui pemeriksaan mendalam terlebih dahulu, melainkan bentuk penyelesaian sederhana dan praktis yang ditempuh dengan jalan damai (berdasarkaan Pasal 47 Undang-Undang Perlindungan Konsumen). Sebagai penyelesaian perdamaian, maka tetap terbuka kemungkinan untuk menuntut pelaku usaha secara pidana.

Mediasi, konsiliasi atau penilaian ahli, ada pihak ketiga yang ikut membantu pihak yang bersengketa menemukan jalan penyelesaian di antara mereka. Pihak ketiga yang dimaksud di sini adalah pihak yang netral, tidak memihak kepada salah satu pihak yang bersengketa. Di sini pihak ketiga tidak memberi putusan atas sengketa, tetapi membantu para pihak menemukan penyelesaiannya.

Jika si pelaku usaha tidak mau menyelesaikan tuntutan ganti rugian tersebut atau di antara mereka tidak ada penyelesaian, pembeli dapat mengajukan kasus tersebut ke atau ke pengadilan. Mengenai badan mengenai badan yang memeriksa dan menyelesaikan sengketa, dalam hal ini atau pengadilan sepenuhnya bergantung pada pilihan secara sukarela dari pihak-pihak yang bersangkutan (Pasal 45 ayat (2) Undang-Undang Perlindungan Konsumen). Mengikuti ketentuan Pasal 23 Undang-Undang Perlindungan Konsumen, penyelesaian sengketa konsumen melalui ini dapat ditempuh, yaitu jika penyelesaian secara damai di luar proses pengadilan ini dapat ditempuh, baik karena produsen menolak atau tidak memberi tanggapan maupun jika tidak tercapai kesepakatan.

Tugas melaksanakan penanganan dan penyelesaian sengketa konsumen, dengan cara melalui mediasi, arbitrase, konsiliasi, memberikan konsultasi perlindungan konsumen; melakukan pengawasan terhadap pencantuman klausula baku; melaporkan kepada penyidik umum apabila terhadap pelanggaran ketentuan dalam UndangUndang Nomor 8 Tahun 1999 tentang Perlindungan Konsumen; menerima pengaduan 
Perlindungan Terhadap Konsumen dalam Jual Beli Rumah. ..(Ni Putu Yunika Sulistyawati, Ni Made Yuniari, I Nyoman Agus Trisnadiasa, 18-26 )

baik tertulis maupun tidak tertulis, dari konsumen tentang terjadinya pelanggaran terhadap perlindungan konsumen; melakukan penelitian dan pemeriksaan sengketa perlindungan konsumen; memanggil pelaku usaha yang diduga telah melakukan pelanggaran terhadap perlindungan konsumen; memanggil dan menghadirkan saksi, saksi ahli dan/atau setiap orang yang dianggap mengetahui pelanggaran terhadap UndangUndang Perlindungan Konsumen; meminta bantuan penyidik untuk menghadirkan pelaku usaha, saksi, saksi ahli, atau setiap orang atau pihak yang tidak bersedia memenuhi panggilan badan penyelesaian sengketa konsumen; mendapatkan; meneliti dan/atau menilai surat, dokumen atau alat bukti lain guna penyelidikan dan/atau pemeriksaan; memutuskan dan menetapkan ada atau tidaknya adanya kerugian di pihak konsumen; memberitahukan putusan kepada pelaku usaha yang melakukan pelanggaran terhadap perlindungan konsumen; menjatuhkan sanksi administratif kepada pelaku usaha yang melanggar ketentuan undang-undang ini.

Pemeriksaan atas permohonan/tuntutan konsumen dilakukan sama seperti persidangan dalam pengadilan umum, yaitu ada pemeriksaan terhadap saksi, saksi ahli, dan bukti-bukti lain.

Dalam hal tuntutan diajukan melalui pengadilan, dipersoalkanlah proses atau tahapantahapan pemeriksaan tuntutan ganti rugi sehubungan dengan pertanggungjawaban produsen/pelaku usaha.

Dalam sengketa konsumen, pihak-pihak yang digugat adalah produsen, yaitu segala pihak yang ikut serta di dalam penyediaan dan peredaran produk hingga sampai ke tangan konsumen. Jadi, sangat mungkin terdiri dari beberapa orang (pihak) yang berbeda. Dalam hal seperti ini jika tergugat ada beberapa orang, dapat dipilih di tempat tinggal salah satu tergugat sebagai tempat mengajukan gugatan.

Pada umumnya gugatan itu diajukan secara tertulis. Namun demikian, gugatan pun dapatlah diajukan secara lisan kecuali kuasanya. Pengajuan gugatan disertai dengan pembayaran sejumlah uang dministrasi yang besarnya ditetapkan oleh ketua pengadilan negeri setempat.

Uraian tentang kejadian merupakan penjelasan duduknya perkara, sedang uraian tentang hukum ialah uraian tentang adanya hak atau hubungan hukum yang menjadi dasar yuridis daripada tuntutan. Di sini konsumen sebagai penggugat menguraikan dengan jelas hubungan hukum antara produsen dan konsumen sampai pada peristiwa adanya kerugian yang diderita konsumen. Hubungan hukum itu dapat berupa hubungan yang timbul karena adanya perjanjian (kontrak) atau dapat pula berupa hubungan hukum yang timbul karena terjadinya peristiwa melanggar hukum. Jadi, ada dua peristiwa yang dapat diajukan sebagai dasar hak konsumen untuk mengajukan tuntutan, yaitu peristiwa wanprestasi dan perbuatan melanggar hukum.

Pada bagian akhir gugatan dimuat petitum, yaitu tuntutan apa yang oleh penggugat diminta atau diharapkan akan diputuskan oleh hakim. Jadi, petitum itu akan mendapatkan jawabannya di dalam dictum atau amar putusan.

Membiarkan sengketa dagang terlambat diselesaikan akan mengakibatkan perkembangan pembangunan ekonomi tidak efisien, produktivitas menurun, dunia bisnis mengalami kemandulan, dan biaya produksi meningkat. Konsumen adalah pihak yang paling dirugikan. Disamping itu, peningkatan kesejahteraan dan kemajuan sosial kaum pekerja juga terhambat.

Penyelesaian sengketa berdasarkan Pasal 45 Undang-Undang Perlindungan Konsumen, yaitu:

(1)Setiap konsumen yang dirugikan dapat menggugat pelaku usaha melalui lembaga yang bertugas menyelesaikan sengketa antara konsumen dan pelaku usaha atau melalui peradilan yang berada di lingkungan peradilan umum.

(2)Penyelesaian sengketa konsumen dapat ditempuh melalui pengadilan atau di luar pengadilan berdasarkan pilihan sukarela para pihak yang bersengketa.

(3)Penyelesaian sengketa di luar pengadilan sebagaimana dimaksud pada ayat (2) tidak 
menghilangkan tanggung jawab pidana sebagaimana diatur dalam undang-undang.

(4)Apabila telah dipilih upaya penyelesaian sengketa konsumen di luar pengadilan, gugatan melalui pengadilan hanya dapat ditempuh apabila upaya tersebut dinyatakan tidak berhasil oleh salah satu pihak atau oleh para pihak yang bersengketa.

Untuk mengatasi keberlakuan proses pengadilan, Undang-Undang Perlindungan Konsumen memberi jalan arternatif dengan menyediakan penyelesaian sengketa diluar peradilan. Dalam Pasal 45 ayat (4) UndangUndang Perlindungan Konsumen, menyebutkan : "Jika telah dipilih upaya penyelesaian sengketa konsumen di luar pengadilan, gugatan melalui pengadilan hanya dapat ditempuh jika upaya itu dinyatakan tidak berhasil oleh salah satu pihak atau oleh para pihak yang bersengketa". Ini berarti, penyelesaian di pengadilan pun tetap dibuka setelah para pihak gagal menyelesaikan sengketa mereka diluar pengadilan.

Jika yang dimaksud dengan "penyelesaian diluar pengadilan" tentu saja tidak mungkin ada kesan bahwa salah satu pihak atau para pihak dapat menghentikan perkaranya di tengah jalan, sebelum menjatuhkan putusan. Dengan demikian, kata-kata "dinyatakan tidak berhasil" pun tidak mungkin dapat dilakukan begitu saja oleh salah satu pihak atau para pihak. Sekali mereka memutuskan untuk memilih penyelesaian melalui, maka mereka seharusnya terikat untuk menempuh prose pemeriksaan sampai saat penjatuhan putusannya.

Sebagaimana disebutkan dalam Pasal 1865 KUHPerdata, peristiwa yang menjadi dasar hak itu harus dibuktikan oleh penggugat. Artinya, kalau gugatan atas ganti kerugian didasarkan pada peristiwa wanprestasi, konsumen sebagai penggugat perlu membuktikan :

1) Adanya hubungan perikatan (kontrak, perjanjian);

2) Adanya bagian-bagian dari kewajiban yang tidak dipenuhi oleh produsen; dan

3) Timbulnya kerugian bagi konsumen (penggugat).
Dalam hubungannya dengan tanggung jawab produk, pada gugatan yang diajukan konsumen yang berada dalam hubungan kontrak jual beli, ia harus membuktikan wanprestasi tergugat-produsen. Wanprestasi yang harus dibuktikan itu meliputi seluruh kewajiban yang tidak dilaksanakan oleh produsen sebagai tergugat, yaitu kewajiban-kewajiban yang tidak dilaksanakan menurut perjanjian jual beli termasuk kewajiban untuk menanggung cacat tersembunyi. Jadi, pedoman untuk membuktikan dipenuhi atau tidak dipenuhinya kewajiban produsen penjual adalah perjanjian yang sudah ada. Di sini, norma yang dilanggar adalah norma kontraktual. Pada gugatan yang didasarkan pada wanprestasi, konsumen penggugat tidak perlu membuktikan adanya kesalahan terguggat sehingga ia wanprestasi. Jadi, cukup dengan menunjukkan bukti-bkti bahwa produsen tergugat telah tidak melaksanakan kewajibannya dengan baik.

Perlindungan konsumen dalam perjanjian jual beli rumah sangat penting karena konsumen perlu dibina dan dilindungi untuk tidak senantiasa menjadi korban perjanjian jual beli rumah yang dibuat oleh developer tersebut dan konsumen perlu pendidikan serta disadarkan untuk mengajukan keberatan dan menolak syarat-syarat perjanjian yang telah dibakukan yang terdapat pada setiap perjanjian yang dibuat oleh developer, melalui penelitian ini diharapkan memberikan draf perjanjian antara konsumen dan developer serta adanya evaluasi tentang Perlindungan terhadap Konsumen Dalam Jual Beli Rumah Melalui Developer di Kota Denpasar terutama masalah yang ditemukan dilapangan tentang perjanjian yang dibuat developer dan konsumen tanpa penjelasan lebih rinci hak dan kewajiban developer dan konsumen.

Kurangnya sarana pendidikan dan pembinaan konsumen serta belum adanya suatu Lembaga Swadaya Masyarakat di bidang perumahan seperti lembaga appraisal yang dapat memberikan penilaian terhadap mutu bangunan serta dapat mewakili konsumen dalam memperjuangkan hak-haknya, terbukti di beberapa lokasi perumahan di Denpasar yang 
Perlindungan Terhadap Konsumen dalam Jual Beli Rumah. ..(Ni Putu Yunika Sulistyawati, Ni Made Yuniari, I Nyoman Agus Trisnadiasa, 18-26 )

dibuat oleh developer terdapat beberapa pelanggaran hak-hak konsumen yang menyangkut hak atas keselamatan, seperti mutu bangunan tidak sesuai dengan standar, saluran akhir dari air limbah/ hujan yang tidak tersalur sehingga menyebabkan banjir belum terlaksana secara efektif.

Tentang Perlindungan terhadap konsumen dalam jual beli rumah melalui developer dikota denpasar dalam hal ini masalah antara konsumen dan developer yang menyangkut hak kenyamanan keamanan dalam menempati rumah yang dibeli dari pihak developer. Pihak developer menyatakan bangunan sudah sesuai dengan bestek, tetapi dari konsumen tidak ikut mengawasi pembangunan rumah, selain itu juga karena awam terhadap mutu bangunan sehingga tidak dapat menilai mutu bangunan tersebut.

Perlindungan terhadap konsumen dalam jual beli rumah melalui developer dikota denpasar dari hasil penelitian hanya sebatas kerusakankerusakan kecil pada saat garansi yang diberikan oleh developer, dalam hal jual beli rumah melalui developer di kota Denpasar yang menyangkut masalah hak konsumen baik keselamatan, kenyamanan dan keamanan dalam menempati rumah yang dibeli melalui pihak perumahan". Adapun penyelesaian masalah antara developer dan konsumen Pasal 52 Undang-Undang Nomor 8 Tahun 1999 tentang Perlindungan Konsumen dan belum adanya penyelesaian dilembaga peradilan. Dalam tataran empiris penyelesaiannya memilih jalan musyawarah mufakat dan apabila tidak ada kesepakatan kedua belah pihak, maka meminta bantuan Notaris sebagai mediator.

\section{Kendala-kendala yang dihadapi oleh developer maupun konsumen dalam menyelesaikan sengketa undang-undang Nomor 8 Tahun 1999 tentang perlindungan konsumen, yaitu :}

Berdasarkan penelitian pada developer di kota Denpasar Bahwa secara garis besarnya kendala-kendala yang dialami dalam menyelesaikan masalah penyelesaian sengketa antara konsumen dan developer, yaitu :

1. Kendala-kendala yang didihadapi secara yuridis yaitu kendala-kendala hukum yang ditemukan sehubungan dengan dipenuhinya peraturanperaturan perundang-undangan. Kendala yang dihadapi secara yuridis yaitu karena ketidak pahaman konsumen dan developer terhadap keberadaan Undang-undang Nomor 8 Tahun 1999 tentang Perlindungan Konsumen serta kurangnya sosialisasi dimasyarakat tentang adanya Undang-undang perlindungan konsumen. Dari pihak developer kurangnya mensosialisasikan tentang undang-undang perlindungan konsumen, dan mempeyampaikan hak-hak apa saja yang diperoleh oleh konsumen dan kewajiban apa saja yang nantinya yang dipenuhi oleh pihak konsumen. Dari pihak konsumen kelemahanya kurangnya pengetahuan konsumen terhadap hukum perlindungan konsumen, dalam hal ini dimungkinkan karena tidak adanya sosialisasi terhadap masyarakat awam tidak paham benar tentang hukum, maka itulah bayak konsumen yang meneluhkan selain kepada pihak developer kemana lagi harus menyampaikan masalahnya, dari sinilah kelihatan tidak efektifitasnya.

2. Dalam hal ini kendala-kendala non yuridis yang dihadapi diluar ketentuan peraturan-peraturan yang berlaku, sebagai berikut : Kendala secara non yuridis dalam hal ini dikarenakan sumber daya manusia yang kurang, selain itu fasilitas dan sarana yang tidak mendukung. Dari segi sarana dan fasilitas lainnya, tidak ada di Bali dan perlu diadakan. Jadi sarana dan fasilitas mencakup tenaga manusia yang berpendidikan dan terampil, organisasi, peralatan yang memadai tidak terpenuhi standarnya. Diupayakan nantinya bisa dan mampu menyelesaikan masalah penyelesaian permasalahan konsumen perumahan di Denpasar tidak ada. Kendala yang lain adalah kurangnya aspirasi konsumen untuk memilih menyelesaikan kasus penyelesaian konsumen sampai ke jalur peradilan atau litigasi.

\section{Upaya-upaya yang dilakukan baik oleh developer maupun konsumen dalam menghadapi hambatan di dalam penyelesaian jual beli rumah melalui developer, yaitu :}

upaya-upaya yang dilakukan developer dalam menghadapi kendala-kendala pada proses 
penyelesaian sengketa jual beli rumah melaui developer.

Hadjon menyebutkan, ada 2 macam perlindungan hukum bagi rakyat yaitu:

1) Perlindungan Hukum Preventif: Kepada rakyat diberi kesempatan untuk mengajukan keberatan atau pendapatnya sebelum suatu keputusan pemerintah mendapat bentuk yang definitive. Bertujuan mencegah terjadinya sengketa. Perlindungan hukum preventif sangat besar artinya bagi pemerintah yang didasarkan kebebasan bertindak karena dengan adanya perlindungan hukum preventif, pemerintah terdorong untuk bersifat hati-hati dalam mengambil keputusan. Dengan pengertian demikian, penanganan perlindungan hukum bagi rakyat oleh peradilan umum di Indonesia termasuk kategori perlindungan hukum represif. Dalam kaitannya dengan penyelesaian sengketa jual beli rumah melalui developer baik dapat dilakukan melalui upaya preventifmaupun upaya refresif.

Upaya Preventif ( Pencegahan) Upaya ini dilakukan oleh developer untuk meminimalisir terjadinya sengketa atau mencegah kendalakendala yang dihadapi oleh developer sehubungan dengan apabila terjadinya sengketa. Tindakan pertama yang dilakukan oleh developer dalam kaitanyan dengan upaya prenfentif atau (pencegahan) tersebut adalah dengan lebih memperhatikan hak-hak konsumen sesuai dengan apa yang diperjanjikan atau sesuai dengan isi perjanjian dan melukukan pendekatan kepada konsumen tentang rumah yang akan dipasarkan. Upaya pencegahan yang dilakukan Oleh developer lebih diutamakan melalui pendekatan persuasif kepada konsumen. Pendekatan persuasif yang dimaksud adalah pendekatan secara kekeluargaan dengan tujuan menghasilkan musyawarah dan mufakat tentang bagaimana jalan keluar dari penyelasaian sengketa konsumen antara developer dan konsumen, apabila dalam hal ini tidak adanya kesepakatan kedua belah pihak maka mengunakan jasa mediator dari pihak notaris.

Para mediator ini dapat bertindak baik atas inisiatifnya sendiri, menawarkan jasanya sebagai mediator, atau menerima tawaran untuk menjalankan fungsinya atas permintaan dari salah satu atau kedua belah pihak yang bersengketa. Dalam hal ini, agar mediator dapat berfungsi, diperlukan kesepakatan atau konsensus dari para pihak sebagai prasyarat utama.

Pihak developer dalam hal menyatakan :"upaya pendekatan secara kekeluargaan akan menghasilkan penyelesaian sengketa konsumen dalam jual beli rumah melalui developer yang maksimal dari pada jalur hukum, akan tetapi didalam penyelesaian tersebut membutuhkan kesabaran dan proatif dari pihak developer untuk menawarkan solusi kepada konsumen".

Upaya penyelesaian masalah jual beli rumah melalui developer melalui cara kekeluargaan yang biasanya diterapkan oleh developer tersebut melalui beberapa tahap yaitu :

1. Melalui pendekatan dengan konsumen dalam hal ini memberikan kesempatan tenggang waktu memberikan garansi 1 sampai 2 bulan setelah rumah itu ditempati oleh konsumen dan bahkan melalui hasil penelitian yang lain ada juga memberikan garansi selama 15 tahun.

2. Apabila dalam tenggang waktu yang diberikan konsumen tidak juga menyampaikan keluhannya maka maka developer menggap tidak ada masalah.

Ada pula konsumen yang mengeluhkan, karena lokasi rumahnya di tempat datar dan saluran air tidak dipikirkan oleh developer sehingga setiap musim hujan halaman rumahnya menjadi banjir. Masalah yang timbul selain itu adalah masalah saluran akhir yang mengakibatkan genangan air masuk ke dalam halaman rumah, juga masalah kabel listrik tegangan tinggi yang ada di atas atap rumah yang dijanjikan oleh developer pada waktu transaksi penyerahan. Mengenai mutu bangunan, dalam hal ini para konsumen menyatakan kurang mengetahui karena mereka selain awam tentang bangunan, mereka juga tidak ikut mengawasi pembangunan, yang penting mereka menerima rumah itu sesuai dengan bestek yang ada di gambar atau brosur dan sesuai pula dengan perjanjian. Dalam hal ini, supaya mengurangi terjadinya masalah antara konsumen dan developer. 
Perlindungan Terhadap Konsumen dalam Jual Beli Rumah. ..(Ni Putu Yunika Sulistyawati, Ni Made Yuniari, I Nyoman Agus Trisnadiasa, 18-26 )

2. Upaya RefresifPerlindungan Hukum Represif : bertujuan menyelesaikan sengketa

Bentuk upaya represif yang dilakukan oleh developer penyelesaian sengketa terkait dengan mengatasi kendala yuridis sebagai akibat adanya masalah yang dihadapi konsumen. Apabila terjadi sengketa antara konsumen dan pihak developer maka diadakan pertemuan antara konsumen dengan pihak developer sehingga tercapainya musyawarah mufakat, jika tidak diketemukan kesepakatan antara mereka baru meminta bantuan pihak ketiga dalam hal ini sebagai mediator. Dengan adanya kesepakatan ini, maka dapat dilihat bahwa penyelesaian sengketa konsumen perumahan dan lebih memilih jalan kekeluargaan untuk mencapai suatu kesepakatan.

Apabila nantinya ada penyelesaian sengketa yang dilakukan melalui pengadilan, semua biaya yang timbul sehubungan dengan pemeriksaan oleh pengadilan menjadi beban dan harus dibayar oleh para pihak untuk jumlah yang sama, yaitu pihak pertama $50 \%$ dan pihak kedua $50 \%$. Memang dari segi keadilan penyelesaian sengketa tersebut tidak adil karena posisi konsumen diwajibkan menanggung biaya lagi, karena dalam hal ini developer yang seharusnya menanggung semua biaya perkara dan kesalahannya ditangan developer.

\section{Kesimpulan}

Bertitik tolak dari uraian-uraian sebelumnya, hasil analisa dari tulisan ini maka, maka kesimpulan yang dapat diambil adalah sebagai berikut :

(1) Perlindungan terhadap konsumen dalam jual beli rumah melalui developer dikota denpasar dari hasil penelitian hanya sebatas kerusakankerusakan kecil pada saat garansi yang diberikan oleh developer, dalam hal jual beli rumah melalui developer di kota Denpasar yang menyangkut masalah hak konsumen baik keselamatan, kenyamanan dan keamanan dalam menempati rumah yang dibeli melalui pihak Developer". Adapun penyelesaian masalah antara developer dan konsumen Pasal 52 Undang-Undang Nomor 8 Tahun 1999 tentang Perlindungan Konsumen..
Dalam tataran empiris penyelesaiannya memilih jalan musyawarah mufakat dan apabila tidak ada kesepakatan kedua belah pihak, maka meminta bantuan Notaris sebagai mediator.

(2) Kendala-kendala yang dihadapi oleh developer maupun konsumen dalam menyelesaikan sengketa undang-undang Nomor 8 Tahun 1999 tentang perlindungan konsumen, yaitu :

(a) Kendala yang dihadapi secara sosio yuridis yaitu dikarenakan ketidak pahaman konsumen dan developer terhadap keberadaan UndangUndang Perlindungan Konsumen, serta kurangnya sosialisasi di masyarakat tentang adanya Undang-Undang Perlindungan Konsumen. Selain daripada itu, tidak adanya lembaga khusus yang menangani penyelesaian sengketa konsumen, yang dalam hal ini di Kota Denpasar.

(b)Kendala secara non yuridis dalam hal ini dikarenakan sumber daya manusia, baik yang ada pada pihak developer maupun pihak konsumen yang kurang, selain itu fasilitas dan sarana yang tidak mendukung. Oleh karena itu, diupayakan agar nantinya bisa dan mampu menyelesaikan masalah penyelesaian sengketa konsumen perumahan di Kota Denpasar. Kendala yang lain adalah kurangnya aspirasi konsumen untuk memilih dalam menyelesaikan kasus penyelesaian sengketa konsumen sampai ke jalur peradilan.

(3) Upaya-upaya yang dilakukan baik oleh developer maupun konsumen dalam menghadapi hambatan di dalam penyelesaian jual beli rumah melalui developer, yaitu:

Ada 2 macam perlindungan hukum bagi rakyat yaitu sebagai berikut :

1. Upaya Preventif (Pencegahan)

Tindakan yang dilakukan oleh developer dalam kaitanya dengan upaya preventif atau pencegahan tersebut adalah dengan lebih memperhatikan hakhak konsumen, sesuai dengan apa yang diperjanjikan atau sesuai dengan isi perjanjian serta melakukan pendekatan kepada konsumen tentang rumah yang akan dipasarkan melalui : 
a) Pemberian kesempatan tenggang waktu untuk memberikan garansi 1 sampai 2 bulan dan bahkan ada sebuah developer di denpasar memberikan garansi sampai 15 tahun setelah rumah itu ditempati oleh konsumen

b) Apabila dalam tenggang waktu yang diberikan konsumen tidak juga menyampaikan keluhannya maka developer menganggap tidak ada masalah.

\section{Upaya Refresif}

Apabila terjadi masalah antara pihak konsumen dengan pihak developer maka perlu diadakan pertemuan antara konsumen dengan pihak developer, sehingga tercapai musyawarah mufakat. Akan tetapi bilamana tidak ditemukan kesepakatan antara kedua belah pihak, maka meminta bantuan kepada pihak ketiga sebagai Mediator. Dengan adanya kesepakatan ini, maka menunjukkan bahwa penyelesaian sengketa konsumen perumahan lebih banyak memilih jalan kekeluargaan untuk mencapai suatu kesepakatan.

\section{DAFTAR BACAAN}

AZ. Nasution, 1995, Konsumen dan Hukum, Pustaka Sinar Harapan, Jakarta.

Darji Darmodiharjo,1999, Pokok-pokok Filsafat Hukum. PT Gramedia pustaka utama.

Departemen Pendidikan dan Kebudayaan, 1998, Kamus Hukum.

Departemen Pendidikan Nasional, 2005, Kamus Besar Bahasa Indonesia, Edisi Ketiga, Balai Pustaka, Jakarta.

Erman Rajagukguk, 2000. Peranan Hukum Indonesia : Menjaga Persatuan, Memulihkan Ekonomi dan Memperluas Kesejahteran Sosial; Universitas Indonesia, Jakarta.

Hardjon M. Philippus, 1988. Perlindungan Hukum bagi Rakyat Indonesia, Bina Ilmu ,Surabaya.
J.S. Badudu dan Sutan Muhammad Zain, 2001, Kamus Umum Bahasa Indonesia, Sinar Harapan, Jakarta.

Jimly Asshiddiqie, 2000. Pergeseran-pergeseran Kekuasaan Legislatif \& Eksekutif Universitas Indonesia, Jakarta.

Kamus Bahasa Indonesia Kontemporer, 1991, Balai Pustaka, Jakarta,.

Karen S. Fishman, 1986. An Overview of Consumer Law Adlam Donald P. Rothchild \& David W. Carroll; Consumer Protection Reporting Service, Maryland. Munir Fuady, 2002, Pengantar Hukum Bisnis, PT. Citra Aditya Bakti, Bandung.

Siswantoro Sunarso, 2004, Penegakan Hukum Psikotropika dalam Kajian Sosiologi Hukum, Raja Grafindo Persada, Jakarta.

Soerjono Soekanto 1988, Faktor-faktor Penegakan Hukum Psikotropika dalam Kajian Sosiologi Hukum, Raja Grafindo Persada, Jakarta.

Soerjono Soekanto, 1988, Pokok-Pokok Sosiologi Hukum, PT. Raja Grafindo Perkasa, Jakarta.

Sudaryatmo, 1996, Masalah Perlindungan Konsumen di Indonesia, Cet. I, PT. C 